\title{
Bladder Inverted Papilloma
}

National Cancer Institute

\section{Source}

National Cancer Institute. Bladder Inverted Papilloma. NCI Thesaurus. Code C39859.

A neoplasm of the bladder in which the epithelial cells grow downward into the underlying supportive tissue, which often causes hematuria. 